\title{
Mitochondrial dysregulation and muscle disuse atrophy
}

\section{[version 1; peer review: 2 approved]}

\section{Li Li Ji(D), Dongwook Yeo}

The Laboratory of Physiological Hygiene and Exercise Science, University of Minnesota Twin Cities, Minneapolis, MN, 55455, USA

V1 First published: 11 Sep 2019, 8(F1000 Faculty Rev):1621

https://doi.org/10.12688/f1000research.19139.1

Latest published: 11 Sep 2019, 8(F1000 Faculty Rev):1621

https://doi.org/10.12688/f1000research.19139.1

\section{Abstract}

It is well established that mitochondria play a critical role in the metabolic and physiological adaptation of skeletal muscle to enhanced contractile activity. Several redox-sensitive signaling pathways such as PGC-1a, AMPK, IGF/Akt/mTOR, SIRT, NFkB, and FoxO are involved with extensive crosstalk to regulate vital cellular functions such as mitochondrial biogenesis, mitochondrial fusion and fission dynamics, autophagy/mitophagy, and apoptosis under altered demand and stress. However, when muscles cease contraction, such as during immobilization and denervation, mitochondria undergo a series of detrimental changes characterized by downregulation of PGC-1 1 and antioxidant defense, increased ROS generation, activated FoxO, NFKB, and inflammation, enhanced ubiquitination, and finally mitophagy and apoptotic cascades. The phenotypic outcome of the discord of mitochondrial homeostasis is elevated proteolysis and muscle atrophy. The demonstration that PGC-1 a overexpression via transgene or in vivo DNA transfection can restore mitochondrial homeostasis and reverse myocyte atrophy supports the "mitostasis theory of muscle atrophy".

Keywords

Atrophy, Mitochondria, Muscle, PGC-1a, Redox Signaling

\section{Open Peer Review}

Approval Status

1

2

version 1

11 Sep 2019

Faculty Reviews are review articles written by the prestigious Members of Faculty Opinions. The articles are commissioned and peer reviewed before publication to ensure that the final, published version is comprehensive and accessible. The reviewers who approved the final version are listed with their names and affiliations.

1. David A. Hood, York University, Toronto, Canada

2. Roberto Bottinelli, University of Pavia, Pavia, Italy

Any comments on the article can be found at the end of the article. 


\section{Corresponding author: Li Li Ji (llji@umn.edu)}

Author roles: Ji LL: Conceptualization, Data Curation, Formal Analysis, Funding Acquisition, Investigation, Methodology, Project Administration, Supervision, Writing - Original Draft Preparation, Writing - Review \& Editing; Yeo D: Data Curation, Investigation, Methodology, Writing - Review \& Editing

Competing interests: No competing interests were disclosed.

Grant information: This work was supported by the University of Minnesota Twin Cities.

The funders had no role in study design, data collection and analysis, decision to publish, or preparation of the manuscript.

Copyright: @ $2019 \mathrm{Ji}$ LL and Yeo D. This is an open access article distributed under the terms of the Creative Commons Attribution License, which permits unrestricted use, distribution, and reproduction in any medium, provided the original work is properly cited.

How to cite this article: Ji LL and Yeo D. Mitochondrial dysregulation and muscle disuse atrophy [version 1; peer review: 2 approved] F1000Research 2019, 8(F1000 Faculty Rev):1621 https://doi.org/10.12688/f1000research.19139.1

First published: 11 Sep 2019, 8(F1000 Faculty Rev):1621 https://doi.org/10.12688/f1000research.19139.1 


\section{Introduction}

In mammalian skeletal muscle, the role of mitochondria in maintaining proper oxygen consumption and ATP production, thereby fulfilling metabolic and contractile functions, is well known ${ }^{1}$. Over the past several decades, overwhelming evidence has revealed new cellular roles for this organelle, such as to regulate redox homeostasis between ROS and antioxidant defense as well as to control apoptosis ${ }^{2-4}$. Furthermore, the mitochondrion itself undergoes morphological, structural, and genetic alterations to accommodate the above-mentioned changes, mainly via mitochondrial biogenesis and turnover ${ }^{5-7}$. The latter is controlled by mitochondrial fusion and fission dynamics, ubiquitin proteolysis, and lysosomal-autophagy (mitophagy) pathways $^{8-11}$. Within the past three decades, there have been tremendous integrations of knowledge among biochemistry, molecular biology, immunology, genetics, and cancer research to elucidate the mechanisms for governing cell growth, differentiation, adaptation, and death. Among these discoveries, PGC- $1 \alpha$ has taken the front stage ${ }^{12}$. Indeed, the multiple roles of PGC- $1 \alpha$ to control mitochondrial biogenesis and fusionfission dynamics, its interaction with NFKB and Forkhead box class $\mathrm{O}$ family member proteins (FoxO), and its influences on the Sirt pathway and apoptotic cascades have dominated muscle physiology and exercise physiology ${ }^{13-18}$. Instead of providing an overview of mitochondria, this short communication will focus on the role of this organelle in regulating muscle protein degradation during disuse atrophy. Understanding the cellular mechanisms of muscle atrophy may provide insights into the development of therapeutic treatment for patients suffering from muscle wasting.

A wealth of research has demonstrated that reduction, restriction, or complete cessation of contractile activity of striated muscle due to denervation, bed rest, microgravity, and senescence can lead to the loss of muscle mass and function ${ }^{19}$. The primary outcome of muscle immobilization (IM) is increased proteolysis, oxidative stress, inflammation, and functional deterioration $^{20,21}$. During muscle IM, reduced stimulation from the IGF-Akt-mTOR axis leads to lower protein synthesis, and activation of the ubiquitin-proteolysis and autophagy-lysosomal pathways that enhance protein degradation. The majority of research suggests that increased proteolysis is the main reason for muscle protein loss, although diminished protein synthesis also plays a role ${ }^{20}$.

Atrogin-1 and MuRF1, muscle-specific E3 ubiquitin ligases, activate protein degradation ${ }^{22,23}$ by controlling the ubiquitination and degradation of regulatory (e.g. calcineurin and MyoD) as well as structural (e.g. myosin and troponin I) proteins ${ }^{24-27}$. In particular, remobilization ( $\mathrm{RM})$ of a muscle that experienced a prolonged period of IM does not undo the effects of this IM immediately; rather, IM-RM has been shown to promote ROS generation, activate the NFKB pathway, and subsequently stimulate the expression of pro-inflammatory cytokines such as TNFo, IL-1 $\beta$, and IL- 6 as well as inflammatory myokines and cause oxidative stress ${ }^{28}$.

\section{Critical role of mitochondria in muscle disuse atrophy}

Research over the past two decades suggests that loss of mitochondrial homeostasis (mitostasis) can be a primary reason for observed muscle morphological and functional defects after an extended period of disuse ${ }^{29}$. All experimental models of muscle atrophy consistently revealed prominent reduction of mitochondrial volume density. After two weeks of hindlimb IM in mice, mitochondrial density was decreased by $50 \%$ in several muscles ${ }^{30,31}$, with a further $25 \%$ loss in the third week ${ }^{30}$. Considering the reduction of muscle fiber cross-section area during the corresponding time, the total reduction of mitochondrial quantity is devastating. There is some evidence that the majority of loss was the subsarcolemmal mitochondrial subpopulation $^{32,33}$.

In addition to the quantity change, mitochondrial quality also severely deteriorates during muscle IM. Activities of mitochondrial metabolic enzymes such as citrate synthase (CS) and cytochrome c oxidase (COX) showed a severe reduction, accompanied by a $50 \%$ decline of ATP production rate, indicating the muscle was energy deficient ${ }^{30}$. The abundance of mitochondrial DNA (in proportion to nuclear DNA) also showed a reduction. It is not entirely clear whether the defects shown in mitochondrial quantity and quality were the cause or effect of muscle atrophy; however, there is evidence that the occurrence of mitochondrial deterioration precedes the loss of muscle mass $^{34}$.

A skeletal muscle mitochondrion has a half-life of approximately two weeks; therefore, the decline of its volume can be caused by a decrease of biosynthesis, an acceleration of degradation, or both. Mitochondrial biogenesis is controlled primarily by PGC- $1 \alpha$, co-activation of which promotes the expression of Nrf-1 and Nrf-2, a key step for the gene expression of nuclear-encoded mitochondrial proteins and of Tfam, the key regulator of mitochondrial DNA (mtDNA) biosynthesis ${ }^{35}$. PGC-1 $\alpha$ mRNA and protein levels have been shown to decrease steadily during muscle IM for 1-3 weeks ${ }^{28,30,36,37}$, along with the reduction of Nrf-1 and $\mathrm{Tfam}^{30}$. Whether or not downregulation of PGC- $1 \alpha$ is the primary trigger for the decline of mitochondrial biogenesis still requires verification, as PGC$1 \alpha$ itself is also subject to transcriptional and post-translational regulation by other signaling pathways ${ }^{38}$.

In an atrophying muscle, decreased mitochondrial quality and quantity is also influenced by its degradation, controlled by mitophagy, as well as the fusion and fission dynamics ${ }^{31,39,40}$. A decline of mitochondrial inner membrane potential $\left(\Delta \psi_{\mathrm{m}}\right)$ may serve as the initial signal for the relocation of PINK1 to the mitochondrial membrane, which phosphorylates mitochondrial fusion protein-2 (Mfn2) as the docking point for Parkin, a ubiquitin ligase ${ }^{41}$. Beclin 1, BCL2/Adenovirus E1B 19kDa Interacting Protein 3 (Bnip3), microtubule-associated protein 1 light chain 3 (LC3), and the autophagy adaptor protein $\mathrm{p} 62 / \mathrm{SQSTM} 1$ (p62) are key players for forming the 
autophagosome, which engulfs mitochondria followed by lysosomal degradation ${ }^{41}$. In skeletal muscle, Beclin 1 and Bnip3/nix upregulation are controlled by $\mathrm{FoxO}^{42}$. Activation of this PINK1-Mfn2-Parkin axis facilitates the removal of damaged mitochondria to maintain a healthier mitochondrial pool but decreases overall mitochondrial population in the disused muscle. After two weeks of IM followed by RM, both PINK1 and Parkin expression was increased severalfold ${ }^{31,43}$. Increased mitophagy during IM is a double-edged sword; it eliminates damaged and dysfunctional mitochondria to keep a smaller but healthier mitochondrial population but sacrifices mitochondrial quantity and causes a deficit of energy production.

\section{Crosstalk of signaling pathways during muscle atrophy}

There is strong evidence that alteration of mitochondrial morphological changes due to fusion and fission protein expression affects many vital cellular functions and is critical to mitostasis ${ }^{44}$. Mfn2 repression was shown to decrease the rate of pyruvate and glucose oxidation, reduce mitochondrial membrane potential $\left(\Delta \psi_{\mathrm{m}}\right)$, and cause a dramatic discontinuity of the mitochondrial network ${ }^{45}$. Interestingly, FoxO activation during muscle atrophy promotes the expression of mitochondrial E3 ubiquitin ligase (Mul-1), thus ubiquitinating and degrading $\mathrm{Mfn}^{46}$. Therefore, IM may promote mitochondrial fission and fragmentation partly because of the upregulation of Mul-1 and the subsequent downregulation of $\mathrm{Mfn}^{31}$. Furthermore, Mfn1 and Mfn2 are also substrates for Parkin, suggesting increased mitophagy favors a trend of fission ${ }^{47}$. Notably, Parkin's substrates also include other important proteins such as mitochondrial Pho GTPase, membrane translocase (TOM70, TOM40 and TOM20), and voltage-dependent anion channel proteins $(\mathrm{VDAC})^{41}$. Decreased fusion and increased fission protein expression can make mitochondria more fragmented and easier to be isolated for removal by mitophagy ${ }^{48}$. Figure 1 is an illustration of the interactions of various



Figure 1. Illustration of the effects of muscle immobilization on intracellular signaling pathways causing increased ubiquitin proteolysis and mitophagy. Arrow-headed lines represent activation; dot-ended lines represent inhibition. $26 \mathrm{~S}, 26$ proteasome; Akt, protein kinase B; ATF2, activating transcription factor 2; ATGs, autophagy related proteins; CaMK, $\mathrm{Ca}^{2+} /{ }^{2}$ calmodulin-dependent protein kinase; CaNR, calcineurin; CAT, catalase; COX2, cytochrome c oxidase 2; CREB, cyclic AMP response element-binding protein; Drp1, dynamin-related protein 1; elF4E, eukaryotic translation initiation factor 4E; EP, epinephrine; ERR $\alpha$, estrogen-related receptor alpha; ETC, electron transport chain; Fis 1, mitochondrial fission 1 protein; FoxO, Forkhead box class $\mathrm{O}$ family member proteins; GPx, glutathione peroxidase; IGF-1, insulinlike growth factor 1; IkK, IkB-kinase; IL-1,6, interleukin-1,6; LC3, microtubule-associated protein 1 light chain 3; Mfn2, mitofusin-2; MnSOD, manganese superoxide dismutase; mTOR, mammalian target of rapamycin; Mul-1, mitochondrial E3 ubiquitin ligase; MuRF-1, muscle RING-finger protein-1; NADPHox, nicotinamide adenine dinucleotide phosphate oxidase; NEMP, nuclear-encoded mitochondrial proteins; NRFs, nuclear respiratory factors; p, phosphate; p38, p38 mitogen-activated protein kinase; p50, p65, NFkB subunits; p62, sequestosome 1; p70S6K, ribosomal protein S6 kinase beta-1; PGC-1 $\alpha$, peroxisome proliferator-activated receptor gamma coactivator 1-alpha; PI3K, phosphatidylinositol 3-kinase; PINK1, PTEN-induced kinase 1; PKA, protein kinase A; ROS, reactive oxygen species; SIRT3, sirtuin-3; SOD2, superoxide dismutase 2; Tfam, mitochondrial transcription factor A; TNF $\alpha$, tumor necrosis factor alpha; Ub, ubiquitin. 
signaling pathways that regulate mitochondrial homeostasis and muscle protein degradation.

FoxO signaling plays a number of important parts in skeletal muscle plasticity; these include energy metabolism, protein degradation, and muscle regeneration, among others ${ }^{49}$. In the case of muscle disuse atrophy, FoxO3 is in control of the ubiquitinproteasome and autophagy-lysosome pathways independently. In actively contracting skeletal muscle, the PI3K-Akt-mTOR pathway phosphorylates and inactivates FoxO, thereby inhibiting excessive ubiquitin-proteolysis and mitophagy. Contractionmediated PGC- $1 \alpha$ signaling and mitochondrial biogenesis maintain a healthy mitochondrial turnover and keep FoxO in check via its phosphorylation ${ }^{49}$. Furthermore, PGC-1 $\alpha$ regulates intracellular redox status by reducing ROS generation (due to a healthier mitochondrial population) and upregulating antioxidant enzymes ${ }^{14,30}$. This homeostatic balance can be disrupted within the disused muscle because of mitochondrial membrane damages shown by enhanced lipid peroxidation and ubiquitination ${ }^{30}$. Reduced PI3K-Akt-mTOR pathway activity during muscle IM results in FoxO3 dephosphorylation, which then leads to its nuclear sequestration and DNA binding ${ }^{49,50}$. Furthermore, activated AMPK phosphorylates serines 413 and 588 of FoxO3a, which supports its retention in the nucleus ${ }^{51}$. The activation of FoxO3 increases Atrogin-1 and MuRF-1 transcriptional activity ${ }^{52,53}$. Moreover, prolonged IM can activate $\mathrm{NF \kappa B}$ signaling and increase the production of pro-inflammatory cytokines and myokines such as TNF- $\alpha$, IL-1 $\beta$, IL- 6 , and MCP ${ }^{30,54,55}$. Both TNF- $\alpha$ and IL- $1 \beta$ are known stimulators of ROS generation from the mitochondrial electron transport chain and other oxidases such as NADPH oxidase, COX-2, and lipoxygenase, thus escalating oxidative stress via a vicious cycle.

Crosstalk of catabolic signaling pathways can disrupt mitostasis and elicit catastrophic cascades toward apoptosis in disuse atrophy. During IM, PINK1-Mfn2-Parkin axis-induced mitochondrial ubiquitination, fragmentation, and mitophagic degradation leads to differential expression of $\mathrm{Bcl} 2$ family proteins involved in both autophagy and apoptosis ${ }^{41}$. Muscle IM has been reported to increase the relative content of $\mathrm{Bax}(\mathrm{Bax} / \mathrm{Bcl} 2$ ratio), which is associated with the activation of caspase- $3^{43}$. Bnip3, the pro-apoptotic protein, can be upregulated with IM when increased ROS and inflammation prevail ${ }^{31,43}$. Bax is required for Bnip3-induced loss of mitochondrial inner membrane potential $(\Delta \psi \mathrm{m})$, which further destabilizes the mitochondrial membrane and enhances mitophagic tendency ${ }^{56}$. Furthermore, Bnip3 can induce cell death through atypical apoptosis without caspase-3 and cytochrome c release ${ }^{56}$. These findings suggest that mitochondrial dynamics change and mitophagy is closely related to muscle cell death. Thus, besides decreased myocyte cross-section area (sign of atrophy), myocyte number may also decrease due to apoptosis, although an unequivocal conclusion on this matter still requires more investigation.

\section{In vivo PGC-1 $\alpha$ transfection inhibits muscle atrophy}

Because of the critical role of mitostasis in the pathogenesis of muscle disuse atrophy, various experimental models have been employed to boost mitochondrial biogenesis and to inhibit proteolytic, autophagic, and apoptotic pathways, such as FoxO gene knockout ${ }^{23}$, inhibition of $\mathrm{NF \kappa B}^{57}$, antioxidant intervention, and transgenic overexpression of PGC- $1 \alpha^{37,58}$. Moreover, exercise has been consistently demonstrated to be a very effective way to enhance mitochondrial biogenesis mainly due to the upregulation of PGC- $1 \alpha^{17,18,32}$. These methods have been reviewed extensively in the past; therefore, the following is a brief review of the efficacy of an in vivo DNA transfection technique that overexpresses PGC-1 $\alpha$ in mouse muscle to reveal the mechanism of action ${ }^{30,59}$.

PGC-1 $\alpha$ transfection in vivo was shown to effectively restore PGC- $1 \alpha$ content in the cytoplasm, nucleus, and mitochondria ${ }^{30}$, and overexpression does not seem to be limited by animal age ${ }^{31,59,60}$. As a result, mitochondrial density and mtDNA content were both elevated in the transfected TA muscle, along with higher levels of Tfam, suggesting these improvements were due in part to increased mitochondrial proliferation. Mitochondrial oxidative function showed significant enhancement demonstrated by increased CS, COXIV activity, and ATP production rate. These findings were in general agreement with data obtained in transgenic animal studies overexpressing PGC- $1 \alpha^{57,58}$.

PGC- $1 \alpha$ local transfection decreased muscle oxidative stress, such as lipid and protein oxidative damage ${ }^{30}$. The protection may stem from two events: reduced ROS generation in the mitochondria and increased antioxidant defense ${ }^{30}$. Enhanced mitochondrial biogenesis leads to a "younger" and healthier mitochondrial population with fewer inner membrane defects, which is a main source of ROS generation. Increased PGC- $1 \alpha$ reduced acetylation of mitochondrial SOD (SOD2), making it more active $^{30}$. There is evidence that this protection is caused by PGC- $1 \alpha$-induced upregulation of SIRT3, a mitochondrial deacetylase. Other key mitochondrial enzymes susceptible to acetylation may also be protected by SIRT3 upregulation ${ }^{61}$. PGC- $1 \alpha$ transfection also increased muscle glutathione peroxidase (GPx) and catalase activities that control hydrogen peroxide concentration in the IM muscle ${ }^{30,59}$. Moreover, PGC- $1 \alpha$ overexpression inhibited NFKB and the expression of IMinduced inflammatory cytokines such as TNF $\alpha$, IL-1 $\beta$, and IL-6, which are important negative regulators of mitochondrial homeostasis. Figure 2 summarizes the major effects of in vivo PGC- $1 \alpha$ transfection on muscle mitochondrial and protein homeostasis.

IM-activated mitophagy was shown to be suppressed by PGC-1 $\alpha$ overexpression in both young and aged mouse muscles ${ }^{31,59}$. Major players of mitophagy such as PINK1, Parkin, Mul-1, and LC3II were upregulated in mouse TA muscle after IM, but these effects were mitigated by PGC- $1 \alpha$ transfection. Suppression of FoxO signaling probably played a critical role in this protection because it is the primary activator of mitophagy. As strong supporting evidence, mitochondrial ubiquitination level was attenuated by PGC- $1 \alpha$ transfection. It is interesting to note that PGC- $1 \alpha$ also inhibited Fis-1 and Drp-1 expression in the aged muscle ${ }^{59}$. This finding suggests that ameliorated changes in mitochondrial dynamics by PGC- $1 \alpha$ may attenuate mitochondrial fragmentation, a main reason for higher mitophagy rate in the IM muscle. 


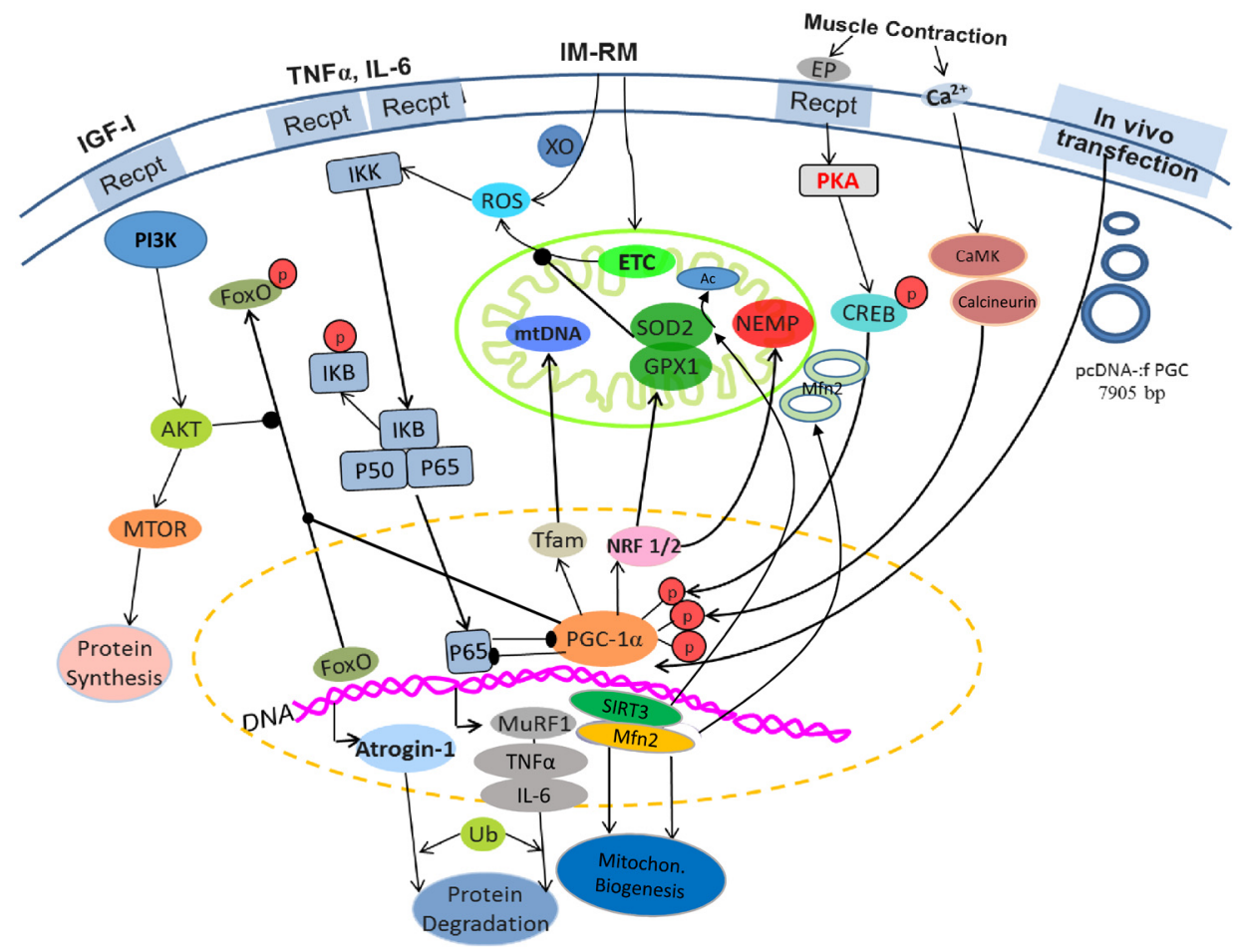

Figure 2. Illustration of the effects of in vivo PGC-1 $\alpha$ transfection on intracellular signaling pathways that promote mitochondrial biogenesis and inhibit ubiquitin proteolysis and mitophagy. Arrow-headed lines represent activation; dot-ended lines represent inhibition. Ac, acetate; Akt, protein kinase B; CaMK, $\mathrm{Ca}^{2+} /$ calmodulin-dependent protein kinase; CREB, cyclic AMP response element-binding protein; PI3K, phosphatidylinositol 3-kinase; EP, epinephrine; ETC, electron transport chain; FoxO, Forkhead box class O family member proteins; GPX1, glutathione peroxidase 1; IGF-1, insulin-like growth factor 1; IKK, IkB-kinase; IL-1,6, interleukin-1,6; IM-RM, immobilizationremobilization; Mfn2, mitofusin-2; MTOR, mammalian target of rapamycin; MuRF1, muscle RING-finger protein-1; NEMP, nuclear-encoded mitochondrial proteins; NRF 1/2, nuclear respiratory factors 1/2; $p$, phosphate; p50, p65, NFkB subunits; pcDNA-:f PGC, PGC-1 $\alpha$ plasmid; PGC-1 $\alpha$, peroxisome proliferator-activated receptor gamma coactivator 1-alpha; SIRT3, sirtuin-3; SOD2, superoxide dismutase 2; Tfam, mitochondrial transcription factor A; TNF $\alpha$, tumor necrosis factor alpha; Ub, ubiquitin; XO, xanthine oxidase.

Recent research indicates that an interplay between PGC- $1 \alpha$ and transcription factor EB (Tfeb) exists in skeletal muscle that regulates the biological outcome of mitochondrial biogenesis and mitophagy ${ }^{62}$. Tfeb is regarded as the master regulator of lysosomal biogenesis in the autophagy process, and exercise has been shown to induce Tfeb expression ${ }^{63}$. One may speculate that high levels of PGC- $1 \alpha$ may decrease Tfeb expression, thereby attenuating mitophagy in an atrophying muscle. Interestingly, several recent studies revealed an opposite result. For example, Vainshtein et al. ${ }^{64}$ showed that Tfeb protein level was elevated in denervation-induced muscle atrophy, whereas transcriptional PGC- $1 \alpha$ overexpression increased muscle Tfeb and most mitophagy-related proteins. Thus, whether or not Tfeb played a role in accounting for the decreased mitophagy in IM muscle is unclear and requires further investigation.

\section{Conclusion}

Skeletal muscle atrophy caused by IM represents a pathophysiological disorder characterized by excessive proteolysis and associated functional defects. Overwhelming evidence suggests that loss of mitochondrial homeostasis plays a critical role wherein decreased mitochondrial biogenesis, disrupted fusion-fission dynamics, and increased ROS generation and inflammation lead to enhanced mitophagy and eventually apoptosis. PGC- $1 \alpha$ is a key transfection cofactor that crosstalks with all major signaling pathways to protect against catabolic signals. Muscle disuse atrophy can be caused by other experimental conditions such as denervation, bedrest, hindlimb unloading, and microgravity. They may share similar molecular mechanisms that cause IM-induced atrophy but may be governed by separate and unique etiological events, which are beyond this short review. It should also be mentioned that the conclusions of this review are primarily drawn from animal, mainly rodent, studies. The outcome and mechanism of human muscle disuse atrophy could be different. Nevertheless, all research to this date emphasizes the role of mitochondria as the most important organelle that controls the progress of muscle disuse atrophy, thus providing a potential target for intervention and treatment. 
1. Dirksen RT: Sarcoplasmic reticulum-mitochondrial through-space coupling in skeletal muscle. Appl Physiol Nutr Metab. 2009; 34(3): 389-95.

PubMed Abstract | Publisher Full Text | Free Full Text

2. Powers SK, Ji LL, Kavazis AN, et al:: Reactive oxygen species: impact on skeletal muscle. Compr Physiol. 2011; 1(2): 941-69. PubMed Abstract | Publisher Full Text | Free Full Text

3. Yun J, Finkel T: Mitohormesis. Cell Metab. 2014; 19(5): 757-66. PubMed Abstract | Publisher Full Text | Free Full Text

4. Desagher S, Martinou JC: Mitochondria as the central control point of apoptosis. Trends Cell Biol. 2000; 10(9): 369-77. PubMed Abstract | Publisher Full Text

5. F Iqbal S, Hood DA: Oxidative stress-induced mitochondrial fragmentation and movement in skeletal muscle myoblasts. Am J Physiol Cell Physiol. 2014; 306(12): C1176-83.

PubMed Abstract | Publisher Full Text | Free Full Text | F1000 Recommendation

6. Yakes FM, Van Houten B: Mitochondrial DNA damage is more extensive and persists longer than nuclear DNA damage in human cells following oxidative stress. Proc Natl Acad Sci U S A. 1997; 94(2): 514-9. PubMed Abstract | Publisher Full Text | Free Full Text

7. Diaz F, Moraes CT: Mitochondrial biogenesis and turnover. Cell Calcium. 2008; 44(1): 24-35.

PubMed Abstract | Publisher Full Text | Free Full Text

8. Youle RJ, van der Bliek AM: Mitochondrial fission, fusion, and stress. Science. 2012; 337(6098): 1062-5

PubMed Abstract | Publisher Full Text | Free Full Text

9. Twig G, Hyde B, Shirihai OS: Mitochondrial fusion, fission and autophagy as a quality control axis: the bioenergetic view. Biochim Biophys Acta. 2008; 1777(9): 1092-7.

PubMed Abstract | Publisher Full Text | Free Full Text

10. Radke $\mathrm{S}$, Chander $\mathrm{H}$, Schäfer $\mathrm{P}$, et al:: Mitochondrial protein quality control by the proteasome involves ubiquitination and the protease Omi. J Biol Chem. 2008; 283(19): 12681-5.

PubMed Abstract | Publisher Full Text | Free Full Text

11. Livnat-Levanon N, Glickman MH: Ubiquitin-proteasome system and mitochondria - reciprocity. Biochim Biophys Acta. 2011; 1809(2): 80-7. PubMed Abstract | Publisher Full Text

12. Handschin C: The biology of PGC-1 $\alpha$ and its therapeutic potential. Trends Pharmacol Sci. 2009; 30(6): 322-9. PubMed Abstract | Publisher Full Text

13. Puigserver $\mathrm{P}, \mathrm{Wu} \mathrm{Z}$, Park $\mathrm{CW}$, et al:: A cold-inducible coactivator of nuclear receptors linked to adaptive thermogenesis. Cell. 1998; 92(6): 829-39. PubMed Abstract | Publisher Full Text

14. Schreiber SN, Emter R, Hock MB, et al.: The estrogen-related receptor alpha (ERRalpha) functions in PPARgamma coactivator 1alpha (PGC-1alpha)induced mitochondrial biogenesis. Proc Natl Acad Sci U S A. 2004; 101(17) 6472-7.

PubMed Abstract | Publisher Full Text | Free Full Text

15. Eisele PS, Salatino S, Sobek J, et al:: The peroxisome proliferator-activated receptor $\gamma$ coactivator $1 \alpha / \beta$ (PGC-1) coactivators repress the transcriptional activity of NF-אB in skeletal muscle cells. J Biol Chem. 2013; 288(4): 2246-60. PubMed Abstract | Publisher Full Text | Free Full Text

16. Cantó C, Auwerx J: PGC-1alpha, SIRT1 and AMPK, an energy sensing network that controls energy expenditure. Curr Opin Lipidol. 2009; 20(2): 98-105. PubMed Abstract | Publisher Full Text | Free Full Text

17. F Chan MC, Arany Z: The many roles of PGC-1 $\alpha$ in muscle--recent developments. Metab Clin Exp. 2014; 63(4): 441-51. PubMed Abstract | Publisher Full Text | Free Full Text | F1000 Recommendation

18. Lira VA, Benton CR, Yan Z, et al.: PGC-1alpha regulation by exercise training and its influences on muscle function and insulin sensitivity. Am J Physiol Endocrinol Metab. 2010; 299(2): E145-61. PubMed Abstract | Publisher Full Text | Free Full Text

19. F Timmons JA, Gallagher IJ: Molecular studies of exercise, skeletal muscle, and ageing [version 1; peer review: 2 approved]. F1000Res. 2016; 5: pii: F1000 Faculty Rev-1087.

PubMed Abstract | Publisher Full Text | Free Full Text | F1000 Recommendation

20. Jackman RW, Kandarian SC: The molecular basis of skeletal muscle atrophy. Am J Physiol Cell Physiol. 2004; 287(4): C834-43.

PubMed Abstract | Publisher Full Text

21. Kandarian SC, Jackman RW: Intracellular signaling during skeletal muscle atrophy. Muscle Nerve. 2006; 33(2): 155-65. PubMed Abstract | Publisher Full Tex

22. F Bodine SC, Latres E, Baumhueter S, et al.: Identification of ubiquitin ligases required for skeletal muscle atrophy. Science. 2001; 294(5547): 1704-8. PubMed Abstract | Publisher Full Text | F1000 Recommendation

23. Gomes MD, Lecker SH, Jagoe RT, et al:: Atrogin-1, a muscle-specific F-box protein highly expressed during muscle atrophy. Proc Natl Acad Sci U S A. 2001; 98(25): 14440-5.

PubMed Abstract | Publisher Full Text | Free Full Text
24. Clarke BA, Drujan D, Willis MS, et al.: The E3 Ligase MuRF1 degrades myosin heavy chain protein in dexamethasone-treated skeletal muscle. Cell Metab. 2007; 6(5): 376-85.

PubMed Abstract | Publisher Full Text

25. Kedar V, McDonough $\mathrm{H}$, Arya $\mathrm{R}$, et al:: Muscle-specific RING finger $\mathbf{1}$ is a bona fide ubiquitin ligase that degrades cardiac troponin I. Proc Natl Acad Sci U S A. 2004; 101(52): 18135-40.

PubMed Abstract | Publisher Full Text | Free Full Text

26. $\mathrm{Li} \mathrm{HH}$, Kedar V, Zhang C, et al:: Atrogin-1/muscle atrophy F-box inhibits calcineurin-dependent cardiac hypertrophy by participating in an SCF ubiquitin ligase complex. J Clin Invest. 2004; 114(8): 1058-71. PubMed Abstract | Publisher Full Text | Free Full Text

27. Tintignac LA, Lagirand J, Batonnet S, et al:: Degradation of MyoD Mediated by the SCF (MAFbx) Ubiquitin Ligase. J Biol Chem. 2005; 280(4): 2847-56. PubMed Abstract | Publisher Full Text

28. Kang C, Ji LL: Muscle immobilization and remobilization downregulates PGC 10 signaling and the mitochondrial biogenesis pathway. J Appl Physiol (1985). 2013: 115(11): 1618-25. PubMed Abstract | Publisher Full Text

29. Romanello V, Sandri M: Mitochondrial biogenesis and fragmentation as regulators of muscle protein degradation. Curr Hypertens Rep. 2010; 12(6): 433-9.

PubMed Abstract | Publisher Full Text

30. Kang C, Goodman CA, Hornberger TA, et al:: PGC-1 $\alpha$ overexpression by in vivo transfection attenuates mitochondrial deterioration of skeletal muscle caused by immobilization. FASEB J. 2015; 29(10): 4092-106. PubMed Abstract | Publisher Full Text | Free Full Text

31. Kang C, Ji LL: PGC-1 $\alpha$ overexpression via local transfection attenuates mitophagy pathway in muscle disuse atrophy. Free Radic Biol Med. 2016; 93 32-40.

PubMed Abstract | Publisher Full Text

32. Adhihetty PJ, Ljubicic V, Menzies KJ, et al.: Differential susceptibility of subsarcolemmal and intermyofibrillar mitochondria to apoptotic stimuli. Am J Physiol Cell Physiol. 2005; 289(4): C994-C1001. PubMed Abstract | Publisher Full Text

33. Krieger DA, Tate CA, McMillin-Wood J, et al.: Populations of rat skeletal muscle mitochondria after exercise and immobilization. $J$ Appl Physiol Respir Environ Exerc Physiol. 1980; 48(1): 23-8.

PubMed Abstract | Publisher Full Text

34. F Brown DA, Perry JB, Allen ME, et al.: Expert consensus document: Mitochondrial function as a therapeutic target in heart failure. Nat Rev Cardiol. 2017; 14(4): 238-250.

PubMed Abstract | Publisher Full Text | Free Full Text | F1000 Recommendation

35. Wu Z, Puigserver $P$, Andersson $U$, et al:: Mechanisms controlling mitochondrial biogenesis and respiration through the thermogenic coactivator PGC-1. Cell. 1999; 98(1): 115-24.

PubMed Abstract | Publisher Full Text

36. Cannavino J, Brocca L, Sandri M, et al:: PGC1- $\alpha$ over-expression prevents metabolic alterations and soleus muscle atrophy in hindlimb unloaded mice. J Physiol. 2014; 592(20): 4575-89.

PubMed Abstract | Publisher Full Text | Free Full Text

37. Sandri M, Lin J, Handschin C, et al:: PGC-1alpha protects skeletal muscle from atrophy by suppressing FoxO3 action and atrophy-specific gene transcription. Proc Natl Acad Sci U S A. 2006; 103(44): 16260-5. PubMed Abstract | Publisher Full Text | Free Full Text

38. $\mathrm{F}$ Kim Y, Triolo M, Hood DA: Impact of Aging and Exercise on Mitochondrial Quality Control in Skeletal Muscle. Oxid Med Cell Longev. 2017; 2017: 3165396. PubMed Abstract | Publisher Full Text | Free Full Text | F1000 Recommendation

39. Harman D: The free radical theory of aging. Antioxid Redox Signal. 2003; $5(5)$ : $557-61$

PubMed Abstract | Publisher Full Text

40. F Sakellariou GK, Pearson T, Lightfoot AP, et al.: Mitochondrial ROS regulate oxidative damage and mitophagy but not age-related muscle fiber atrophy. Sci Rep. 2016; 6: 33944.

PubMed Abstract | Publisher Full Text | Free Full Text | F1000 Recommendation

41. Palikaras K, Tavernarakis N: Mitochondrial homeostasis: the interplay between mitophagy and mitochondrial biogenesis. Exp Gerontol. 2014; 56: 182-8. PubMed Abstract | Publisher Full Text

42. Mammucari C, Milan G, Romanello V, et al:: FoxO3 controls autophagy in skeletal muscle in vivo. Cell Metab. 2007; 6(6): 458-71 PubMed Abstract | Publisher Full Text

43. Kang C, Yeo D, Ji LL: Muscle immobilization activates mitophagy and disrupts mitochondrial dynamics in mice. Acta Physiol (Oxf). 2016; 218(3): 188-197. PubMed Abstract | Publisher Full Text

44. Chan DC: Mitochondrial fusion and fission in mammals. Annu Rev Cell Dev Biol. 2006; 22: 79-99.

PubMed Abstract | Publisher Full Text

45. Bach D, Pich S, Soriano FX, et al: Mitofusin-2 determines mitochondrial 
network architecture and mitochondrial metabolism. A novel regulatory mechanism altered in obesity. J Biol Chem. 2003; 278(19): 17190-7. PubMed Abstract | Publisher Full Text

46. Romanello V, Guadagnin E, Gomes L, et al:: Mitochondrial fission and remodelling contributes to muscle atrophy. EMBO J. 2010; 29(10): 1774-1785 PubMed Abstract | Publisher Full Text | Free Full Text

47. Gegg ME, Cooper JM, Chau KY, et al:: Mitofusin 1 and mitofusin 2 are ubiquitinated in a PINK1/parkin-dependent manner upon induction of mitophagy. Hum Mol Genet. 2010; 19(24): 4861-70. PubMed Abstract | Publisher Full Text | Free Full Text

48. Green DR, Van Houten B: SnapShot: Mitochondrial quality control. Cell. 2011; 147(4): 950-950.e1. PubMed Abstract | Publisher Full Text | Free Full Text

49. Sanchez AM, Candau RB, Bernardi H: FoxO transcription factors: their roles in the maintenance of skeletal muscle homeostasis. Cell Mol Life Sci. 2014; 71(9): 1657-71.

PubMed Abstract | Publisher Full Text

50. Bonaldo $\mathrm{P}$, Sandri M: Cellular and molecular mechanisms of muscle atrophy Dis Model Mech. 2013; 6(1): 25-39. PubMed Abstract | Publisher Full Text | Free Full Text

51. Greer EL, Oskoui PR, Banko MR, et al.: The energy sensor AMP-activated protein kinase directly regulates the mammalian $\mathrm{FOXO}$ transcription factor. J Biol Chem. 2007; 282(41): 30107-19. PubMed Abstract | Publisher Full Text

52. Sandri M, Sandri C, Gilbert A, et al.: Foxo transcription factors induce the atrophy-related ubiquitin ligase atrogin-1 and cause skeletal muscle atrophy. Cell. 2004; 117(3): 399-412.

PubMed Abstract | Publisher Full Text | Free Full Text

53. F Stitt TN, Drujan D, Clarke BA, et al.: The IGF-1/PI3K/Akt pathway prevents expression of muscle atrophy-induced ubiquitin ligases by inhibiting FOXO transcription factors. Mol Cell. 2004; 14(3): 395-403. PubMed Abstract | Publisher Full Text | F1000 Recommendation

54. Guttridge DC, Mayo MW, Madrid LV, et al.: NF-kappaB-induced loss of MyoD messenger RNA: possible role in muscle decay and cachexia. Science. 2000; 289(5488): 2363-6.

PubMed Abstract | Publisher Full Tex
55. Kang C, Shin WS, Yeo D, et al.: Anti-inflammatory effect of avenanthramides via NF-кB pathways in C2C12 skeletal muscle cells. Free Radic Biol Med. 2018; 117 30-6.

PubMed Abstract | Publisher Full Text

56. Zhang J, Ney PA: Role of BNIP3 and NIX in cell death, autophagy, and mitophagy. Cell Death Differ. 2009; 16(7): 939-46. PubMed Abstract | Publisher Full Text | Free Full Text

57. F Handschin C, Chin S, Li P, et al:: Skeletal muscle fiber-type switching, exercise intolerance, and myopathy in PGC-1alpha muscle-specific knock-out animals. J Biol Chem. 2007; 282(41): 30014-21.

PubMed Abstract | Publisher Full Text | F1000 Recommendation

58. Wenz T, Rossi SG, Rotundo RL, et al:: Increased muscle PGC-1alpha expression protects from sarcopenia and metabolic disease during aging. Proc Natl Acad Sci U S A. 2009; 106(48): 20405-10. PubMed Abstract | Publisher Full Text | Free Full Text

59. Yeo D, Kang C, Gomez-Cabrera MC, et al:: Intensified mitophagy in skeletal muscle with aging is downregulated by PGC-1alpha overexpression in vivo. Free Radic Biol Med. 2019; 130: 361-8. PubMed Abstract | Publisher Full Text

60. Yeo D, Kang C, Gomez-Cabrera MC, et al:: Data on in vivo PGC-1alph overexpression model via local transfection in aged mouse muscle. Data Brief. 2019; 22: 199-203.

PubMed Abstract | Publisher Full Text | Free Full Text

61. F Baeza J, Smallegan MJ, Denu JM: Mechanisms and Dynamics of Protein Acetylation in Mitochondria. Trends Biochem Sci. 2016; 41(3): 231-44. PubMed Abstract | Publisher Full Text | Free Full Text | F1000 Recommendation

62. F Hood DA, Tryon LD, Carter HN, et al:: Unravelling the mechanisms regulating muscle mitochondrial biogenesis. Biochem J. 2016: 473(15): 2295-314. PubMed Abstract | Publisher Full Text | F1000 Recommendation

63. F Erlich AT, Brownlee DM, Beyfuss K, et al.: Exercise induces TFEB expression and activity in skeletal muscle in a PGC-1 $\alpha$-dependent manner. Am J Physiol Cell Physiol. 2018; 314(1): C62-C72.

PubMed Abstract | Publisher Full Text | Free Full Text | F1000 Recommendation

64. Vainshtein A, Desjardins EM, Armani A, et al:: PGC-1 $\alpha$ modulates denervationinduced mitophagy in skeletal muscle. Skelet Muscle. 2015; 5: 9 . PubMed Abstract | Publisher Full Text | Free Full Text 


\section{Open Peer Review}

\section{Current Peer Review Status:}

\section{Editorial Note on the Review Process}

Faculty Reviews are review articles written by the prestigious Members of Faculty Opinions. The articles are commissioned and peer reviewed before publication to ensure that the final, published version is comprehensive and accessible. The reviewers who approved the final version are listed with their names and affiliations.

\section{The reviewers who approved this article are:}

\section{Version 1}

\section{Roberto Bottinelli}

Department of Molecular Medicine, University of Pavia, Pavia, Italy

Competing Interests: No competing interests were disclosed.

\section{David A. Hood}

Muscle Health Research Centre, School of Kinesiology and Health Science, York University, Toronto, Canada

Competing Interests: No competing interests were disclosed.

The benefits of publishing with F1000Research:

- Your article is published within days, with no editorial bias

- You can publish traditional articles, null/negative results, case reports, data notes and more

- The peer review process is transparent and collaborative

- Your article is indexed in PubMed after passing peer review

- Dedicated customer support at every stage

For pre-submission enquiries, contact research@f1000.com 